\title{
Restructuring reforms in Turkish teacher education: Modernisation and development in a dynamic environment
}

\author{
Gary M. Grossman ${ }^{\mathrm{a}}$, Margaret K. Sands \\ a Arizona State University, USA \\ ${ }^{\mathrm{b}}$ Graduate School of Education, Bilkent University, 06800 Bilkent, Ankara, Turkey
}

\begin{abstract}
The paper examines the effectiveness of recent reforms in teacher education in Turkey, specifically the restructuring of programmes in university faculties of education. It first, briefly, sets the reforms of the 1990s in an historical context, prior to the 1997 Act which increased the length of compulsory schooling from 5 to 8 years, and the 1998 restructuring of faculties of education. It considers the national need for the restructuring of teacher education and the issues involved. The thrust of the paper is a study of how teacher educators across the country perceive both the changes and their effect on the quality of teacher education, methodology as a discipline, school partnerships, and relationships with the Ministry of National Education.
\end{abstract}

(C) 2007 Elsevier Ltd. All rights reserved.

Keywords: Teacher education; Educational policy; Educational reform; Turkey

\section{Historical context}

The importance of education in Turkey has been well documented in the literature. Mango (2004) reported that it was a fundamental pillar of Atatürk's Republican revolution and the vehicle of choice for carrying forward the goals of modernisation and westernisation to replace the Ottoman past. Over the course of its 83 years, the Turkish Republic has made major efforts to upgrade, transform, and reorientate its education sector. Only national defence spending has exceeded its share of public funds (Hen-Tov, 2004; Ministry of National Education, 2006). Currently, $22 \%$ of tax

\footnotetext{
${ }^{*}$ Corresponding author.

E-mail addresses: Gary.Grossman@asu.edu (G.M. Grossman), msands@bilkent.edu.tr (M.K. Sands).
}

revenue is given to education, the highest allocation any Turkish government ministry receives (Ministry of National Education, 2006). This commitment to education by government is clearly driven by the demands of the Turkish people, $70 \%$ of them having identified education as a 'very big problem' in their country (Pew, 2002). Comparatively, Turkey far out-ranked the rest of Europe in this category, and it was only in two countries of subSaharan Africa that education was identified by a larger share of respondents.

The response to education reflects a genuine concern in a country which sees education as a path to social development. The enormous reduction of adult illiteracy over the past 25 years from $34 \%$ to $13 \%$ bears witness to the social development of Turkey directly related to educational improvement (UNESCO, 2003). In addition, in primary schools 
by 2002 female enrolment had nearly equalled male age-equivalent enrolment (female $87 \%$, male $92.4 \%$ ) and is rapidly closing the gap at the secondary level, from $10.7 \%$ in 1998 to $5.4 \%$ in 2002 (UNICEF, 2003).

The priority given to public education has led to a series of educational reforms over the course of the history of the Turkish Republic, identified by a number of studies (Grossman and Onkol, 2006; Şimşek and Yıldırım, 2001; Dundar and Lewis, 1999), and the focus on education as an engine of social progress has been demonstrably sustained.

While Turkey's intentions have been clear, internal and external pressures such as the perceived need to maintain a strong national defence and its budget implications in the context of scarce resources, as well as a burgeoning rate of population growth, have acted as challenges to this commitment to education. Like most countries Turkey has experienced, and attempted to respond to, the changes introduced by technology and its effects on all social institutions, education prominent among them (Giddens, 2003). Garm and Karlsen (2004) argue that, in Norway, globalisation has intensified the pace of educational reform, teacher education included, and given it a much more clearly political relevance. In Turkey, debate over the role and purpose of education has played prominently in the political arena, as contestants for major office feature education as a major issue (Mango, 2004; Kinzer, 2001). In addition, and more pragmatically, the demand for education services as a consequence of population pressures is clearly evident. Turkey's growth rate has slowed in recent years to about $1.0 \%$, but about half of Turkey's population is of school age (CIA, 2006).

Clearly, the number of young people alone would create pressure on educational resources. However, Turkey is a candidate nation to join the European Union so that in addition to physical infrastructure requirements, such as more classrooms, schools and teachers, Turkey is working to transform the qualitative aspects of education in order to align them more closely with European standards (Grossman and Onkol, 2006).

It was in this environment of rapid change that Turkey introduced reform in teacher education, implemented in the 1990s through the National Education Development Project (NEDP). One component of the NEDP, based at the Turkish Higher Education Council (HEC), was the improvement of pre-service teacher education. It aimed to
Table 1

Number of teachers produced by Turkish university faculties of education

\begin{tabular}{ll}
\hline Year & Number of teachers \\
\hline 1996 & 3910 \\
1997 & 5325 \\
1998 & 5085 \\
1999 & 5405 \\
2000 & 5400 \\
2001 & 21,143 \\
2002 & 25,353 \\
2003 & 31,843 \\
2004 & 33,427 \\
2005 & 34,291 \\
2006 & 36,571 \\
\hline
\end{tabular}

Sources: Higher Education Council (1998), ÖSYM (2006).

update the way in which intending primary and secondary school teachers were trained. During the life of the project, the HEC also made major changes in the structure of the faculties of education: staffing, student numbers, programmes and courses (Grossman et al., 2007). Turkish higher education leaders were engaged in a process of restructuring faculties of education and teacher education programmes in the most dramatic attempt to reform teacher training institutions on a nationwide basis in Turkish history.

One indication of the change is the increase in the number of teachers produced by Turkish faculties of education. Table 1 shows a tremendous and impressive increase, nearly 10 -fold in one decade. These were the years when curriculum reform was implemented and there was increased rigour in teacher education programmes, particularly at the secondary level. The increase is due to the need for more teachers following the 1997 Act (in a 4-year undergraduate programme, the first graduates were in 2001), and the increase in the number of faculties of education.

\section{Restructuring the faculties of education}

The HEC summarised the need for restructuring the faculties of education and education programmes in Turkey as follows (Higher Education Council, 1998).

- Faculties of education preferred to concentrate their teaching and research in subject areas rather than in education. Too many specialist high 
school teachers were produced and there was a shortage of teachers for primary school and preschool.

- Education and arts/science faculties therefore duplicated each other in the teaching of subject knowledge, in research activities including specialist equipment and laboratories, and in physical infrastructure.

- Specialists who could teach methodology in faculties of education were rare because it was subject knowledge that was emphasised, and very few lecturers had themselves taught in school. Pedagogy was neglected as a field of teaching, study and research.

- Coordination between the major employer, the Turkish Ministry of National Education, and the HEC and faculties of education had been weak, causing an oversupply of teachers in some areas and undersupply in others, especially in primary schools where the ministry had to employ as teachers people without training.

- Student teacher work in schools was limited, both in the amount of time given and the activities done there, with little school teacher involvement in the training of new teachers in the schools.

- In 1997, compulsory basic education in Turkey was increased from 5 years to 8, exacerbating teacher shortages. Restructuring aimed to provide a considerable increase in the number of teachers for grades 1-8 in a very short time.

- Undergraduate programmes in the educational sciences produced graduates, but they were not qualified teachers. They had problems finding jobs. Most of these undergraduate programmes were closed, and educational science courses were transferred to graduate level.

Citing the literature of the time, Şimşek and Yildirım (2001) identify the 1990s as 'the years of restructuring and reformation of educational systems' around the world. According to the authors, restructuring reforms in many countries had in common the following characteristics.

- Control: There was a centralised authority which was capable of implementing the restructuring.

- Theory/practice: Subject knowledge or pedagogy was a topic of discussion and disagreement. Overwhelmingly, pedagogy prevailed, along with emphasis on stronger ties between teacher training institutions and schools.
- Quality: Most reform initiatives placed priority on enhancing quality in measurable ways at all points of the system.

- Quantity: There was a mismatch between the numbers of teachers trained and the demand for them in schools.

- Length of training: To qualify as a teacher required longer training and a higher standard of achievement.

The issues listed above were well known to the HEC. While the NEDP based there addressed the academic content of the curricula in the education faculties and how to improve performance in the classroom, the HEC itself addressed the logistical and organizational problems of restructuring. The restructured system had the following goals (Higher Education Council, 1998).

1. Increased quantity: Turkey had to increase dramatically the numbers of teachers (see Table 1), particularly for grades 1-8, and expand their usefulness by adding a second area of speciality. The restructured faculties were required to open new programmes to educate teachers for every school level, and especially to increase numbers to cope with the three extra years of compulsory education added in 1997.

2. Improved quality: National standards for teachers were to be enforced across Turkey's teacher training institutions. An accreditation system for faculties of education was devised and piloted.

3. Master's degree for high school teachers: A new master's-without-thesis programme was introduced for high school teachers.

4. Emphasis on teaching methodologies and professional studies: The purpose of teacher training was to prepare effective teachers. Faculties of education would focus on methodology and student-teacher school experience and practice. The concentration on subject area specialisms in faculties of education was ended. In addition, academic research had to be related to education.

5. Improved relationships between faculties and schools: Faculty-school partnerships were set up to allow coordination, communication and exchange between faculties of education and their partner schools, with emphasis on longer and more relevant student-teacher work in schools.

6. Co-operation with arts/science faculties: Arts/ science faculties would teach subject knowledge to prospective teachers. 
7. Improved coordination between HEC, faculties and the Ministry of National Education: There would be better co-ordination between those who produced teachers and those who employed them.

8. Increased/improved technology: New and more appropriate technology would be needed.

With these goals the restructuring reform was launched. It was also clearly related to the increase of teacher training institutions in Turkey, from 17 in the 1980 s to over 50 by the end of the century (British Council, 1999) and able to utilise the infrastructure and resources of the NEDP teacher education developments (Grossman et al., 2007).

Şimşek and Yıldırım (2001) note that this restructuring reform

will effectively be in place in a few years time with the return of trainees (masters and doctoral level) from abroad, the full functioning of the new equipment (such as computers and overhead projectors), the use of teaching materials developed, and the full adaptation to the new curriculum emphasizing teaching methodology and school practice.

Restructuring of Turkish teacher education was completed in 1999. This paper, through the Fulbright study of teacher education in Turkey conducted in 2003 and 2004, constitutes an evaluation of its effectiveness. The Fulbright study was undertaken by one of the authors, awarded a Fulbright fellowship, as a follow-up to the work which had been done under the NEDP in teacher education 1995-1999, referred to above.

\section{The Fulbright study}

\subsection{Methodology}

The Fulbright study identified teacher educators in Turkey as essential movers in the overall reform effort. Indeed, even though many aspects of Turkish education were affected by the multiple projects being implemented over the course of a decade, the crucial question concerned the extent to which teachers were being trained according to the new model. Therefore, how teacher educators regarded the reforms was of major importance. The restructuring of faculties of education was considered to be significant in facilitating the implementation of the new curriculum. The support of teacher educators for the restructuring, and the degree to which they sustained the transformation of their place of work, were therefore seen as potentially decisive in the success of reforms, both within the university system and in schools.

The Fulbright study of Turkish teacher educators featured a three-part survey of full-time university academics: assistant professors, associate professors, full professors. They were employed in the education faculties of 54 state universities. Approximately one third of the qualifying academics were randomly selected for the sample $(N=457)$, and 170 of these agreed to take part in the study. They completed an on-line questionnaire in Turkish with 82 items including both scaled response and open-ended questions. The survey data were analysed through the use of descriptive and inferential statistical analysis.

A random selection of 38 teacher educators from this sample participated in a follow-up telephone interview to discuss teacher education issues in some depth. Finally, seven leaders were surveyed to obtain and discuss the views of education decision-makers. The interview data were analysed using qualitative techniques; they will be reported in subsequent explorations of the study.

The validity of the on-line questionnaire was ensured through an expert review from five senior bilingual teacher educators at one of the leading teacher education institutions in Ankara. The five had been actively involved in the reforms. They suggested a number of changes in the English version of the questionnaire, ensuring that the proper issues were being addressed. The questionnaire was changed accordingly. Subsequently, they reviewed the Turkish questionnaire which would be placed on-line. This provided for the linguistic equivalence of the instrument (Miller and Salkind, 2002).

Finally, the instrument was tested through the utilisation of the equivalent-form method of reliability. Department faculty, all of whom used both English and Turkish professionally, were asked to take both versions of the questionnaire. Any item not yielding a correlation of at least $r=.85$ was eliminated from the instrument (Zikmund, 2006).

\subsection{Characteristics of teacher educators who responded to the on-line survey}

The characteristics of the teacher educators who responded to the online survey $(N=170)$ are summarised in Table 2. 
Table 2

Characteristics of Turkish teacher educators from 54 public universities

\begin{tabular}{|c|c|c|c|c|c|}
\hline Characteristics & Age range & $\%$ & $N$ & Mean & SD \\
\hline \multicolumn{6}{|l|}{ Geographical region } \\
\hline 1. Marmara (Istanbul area) & & 18.3 & 32 & & \\
\hline 2. Aegean (Izmir area) & & 13.6 & 23 & & \\
\hline 3. Mediterranean (Antalya area) & & 5.3 & 9 & & \\
\hline 4. Southeastern Anatolia (Diyarbakir area) & & 1.8 & 3 & & \\
\hline 5. Central Anatolia (Ankara-Kayseri area) & & 36.7 & 62 & & \\
\hline 6. Eastern Anatolia (Van area) & & 8.9 & 15 & & \\
\hline 7. Black Sea (Samsun-Trabzon area) & & 15.4 & 26 & & \\
\hline Age range & $28-65$ & & & 42.9 & 8.53 \\
\hline Full professors & & 19.4 & 33 & & \\
\hline Associate professors & & 10.6 & 18 & & \\
\hline Assistant professors & & 59.4 & 101 & & \\
\hline Other positions & & 10.6 & 18 & & \\
\hline Duration of position title for 6 years or fewer & & 61.8 & 105 & & \\
\hline Duration of position title for longer than 6 years & & 38.2 & 65 & & \\
\hline Employed at same university more than 12 years & & 43.5 & 74 & & \\
\hline Employed at same university $6-12$ years & & 32.4 & 55 & & \\
\hline Employed at same university fewer than 6 years & & 24.1 & 41 & & \\
\hline Speak at least one foreign language fluently & & 53.5 & 91 of these & & \\
\hline 1. English & & 75.6 & 69 & & \\
\hline 2. German & & 11.1 & 10 & & \\
\hline 3. French & & 5.6 & 5 & & \\
\hline Speak two or more foreign languages fluently & & 7.7 & 13 & & \\
\hline
\end{tabular}

Table 3

Item 50a: My university produces high-quality teachers for the schools

\begin{tabular}{llllll}
\hline & Completely disagree & Disagree & Neither agree nor disagree & Agree & Completely agree \\
\hline Responses $(\%)^{*}$ & 10.7 & 10.7 & 23.1 & 39.6 & 16.0 \\
$N=169$ & 18 & 18 & 39 & 67 & 27 \\
\hline
\end{tabular}

${ }^{*} 100.0 \%$ (percentages are rounded to $100 \%$ ).

Table 4

Item 50b: All or most graduates of teacher training programmes at my university are able to find appropriate jobs in schools

\begin{tabular}{llllll}
\hline & Completely disagree & Disagree & Neither agree nor disagree & Agree & Completely agree \\
\hline Responses (\%) & 14.8 & 12.4 & 14.2 & 39.1 & 19.5 \\
$N=169$ & 25 & 21 & 24 & 66 & 33 \\
\hline
\end{tabular}

The sample was representative of the teacher educators in Turkey by academic rank, geographic dispersion and university faculty size, as the percentages in all areas were roughly parallel to their presence overall.

\section{Survey data}

\subsection{Quality of teachers}

The Fulbright study examined teacher educator views on how the quality of their graduates had improved in recent years. It was done through several items which asked respondents to agree or disagree with a statement utilising a Likert format. Tables 3 and 4 give data about quality and success in job getting.

Other items in the survey examined the quality issue from the consequences of the restructuring reform. Tables 5-7 give information on knowledge of the reform and change at local level.

Clearly, many Turkish teacher educators were aware of the restructuring reform (Table 6). They recognised that changes had occurred at their own 
university; and a majority stated that improvement had been made in terms of teacher quality in that teachers were better trained (Table 7). The relatively large number of 'don't know/not sure' responses shown in Table 7 was because some respondents had positions in the new faculties of education and had no comparison with present results.

The data suggest that about twice as many teacher educators have seen an improvement in teacher education compared with those who have not. It would seem that teacher educators credit the

Table 5

Item 46: How familiar are you with the national effort to restructure teacher education over the past several years?

\begin{tabular}{lllll}
\hline & $\begin{array}{l}\text { Not familiar } \\
\text { at all }\end{array}$ & $\begin{array}{l}\text { Not very } \\
\text { familiar }\end{array}$ & $\begin{array}{l}\text { Somewhat } \\
\text { familiar }\end{array}$ & $\begin{array}{l}\text { Very } \\
\text { familiar }\end{array}$ \\
\hline $\begin{array}{l}\text { Responses } \\
(\%)\end{array}$ & 1.2 & 3.5 & 42.4 & 52.9 \\
$N=170$ & 2 & 6 & 72 & 90 \\
\hline
\end{tabular}

Table 6

Item 48: Are you aware of anything that has been done in the past several years to change the way teachers are being trained at your university?

\begin{tabular}{llc}
\hline & No & Yes \\
\hline Responses (\%) & 21.2 & 78.8 \\
$N=170$ & 36 & 134 \\
\hline
\end{tabular}

Table 7

Item 49: With regard to the changes you cited, would you say that teachers from your university are better trained than they have been in the past?

\begin{tabular}{llll}
\hline & No & Don't know/not sure & Yes \\
\hline Responses (\%) & 29.4 & 18.8 & 51.8 \\
$N=170$ & 50 & 32 & 88 \\
\hline
\end{tabular}

restructuring reform with improving quality, at least as far as their own circumstances are concerned.

\subsection{Master's degree requirement for high school teachers}

The master's requirement was controversial when it was introduced. The argument against was that it would cause a shortage of high school teachers 'because they will now be trained at graduate level' (Higher Education Council, 1998). The Fulbright study asked teacher educators whether this had been the case, and Table 8 gives the results.

The respondents are more equivocal about this aspect of the restructuring reform, but there are more who 'disagree'. Given that such ambivalence among respondents could be a pattern in the data, further inquiry was undertaken. Inspection of the data found that only two structural characteristics of the sample had significant effects on how the item was regarded, both quite modest, as seen in Table 9.

The data in Table 9 suggest that the older Turkish teacher educators were a bit more likely to express concern about potential shortages of high school teachers. However, the effect is slight, and while respondents may consider that the policy could cause some difficulty, the concern is more or less diffuse in the population and not regarded as a major problem.

\subsection{Emphasis on teaching methodologies and effective professional studies}

Several items in the survey explored the extent to which instruction in teaching methodologies had been appropriately enhanced. Tables 10 and 11 report responses.

The data show that a majority in both items $(57.0 \%$ and $54.1 \%)$ consider that teaching methodologies are emphasised. Further, the degree of inter-correlation between these items is quite high $\left.\left(r=.76^{*}, p<.05\right)\right)$, suggesting that the faculties of education have focus to the extent that teaching methodology is regarded as a discipline.

Table 8

Item 50h: The emphasis on master's level education for secondary teachers is causing a shortage of secondary teachers produced by my university

\begin{tabular}{llllll}
\hline & Completely disagree & Disagree & Neither agree nor disagree & Agree & Completely agree \\
\hline Responses $(\%)$ & 28.2 & 14.1 & 34.7 & 16.5 & 6.5 \\
$N=170$ & 48 & 24 & 59 & 28 & 11 \\
\hline
\end{tabular}




\subsection{Improved relationships between faculties and schools}

Partnerships between faculties of education and schools in their locality were set up nationwide in 1998. They aimed to improve coordination between both partners so that trainee teachers would be better prepared by longer and more relevant school experience.

In Turkey, newly qualified teachers are employed by the ministry across the country, not necessarily in the area where they graduated. Faculties of education do not therefore have natural links with local schools through their past graduates. In order to make such links, the faculty must actively seek them by establishing connections with partner schools. The partnerships work, therefore, if the presence of

Table 9

Zero-order Pearson product-moment correlations between 'Secondary Teacher Shortage' concerns and characteristics of Turkish teacher educators

\begin{tabular}{ll}
\hline & Teacher shortage \\
\hline Duration of position at university & $-.190^{*}$ \\
Total years worked at current university & $-.175^{*}$ \\
\hline
\end{tabular}

$* p>.05$. this outreach from the faculty of education is seen. The Fulbright study showed the results in Table 12 .

Just over half the respondents said that such partnerships were in place. This is a noteworthy finding, given how unusual such close links were in the past.

\subsection{Cooperation with arts/science faculties}

Restructuring involved redirecting faculty of education resources away from teaching subject content and towards methodology and education. In practical terms, arts/science faculties were required to shoulder the burden of increased numbers of undergraduates registered as faculty of education students, which necessitated coordination and cooperation between them. The data from the Fulbright study relating to this point are given in Tables 13 and 14.

Two notable points here: first, only a third agreed that there was a 'high degree' of cooperation between the faculties, indicating that this aspect of the restructuring was not effective. Faculty buildings may be at some distance from each other, regular interactions between teachers of both faculties may be few, the arts/science departments have their own undergraduate programmes and

Table 10

Item 50d: Teacher training programmes at my university have a strong focus on teaching methodologies

\begin{tabular}{llllll}
\hline & Completely disagree & Disagree & Neither agree nor disagree & Agree & Completely agree \\
\hline Responses (\%) & 7.7 & 15.3 & 20 & 39.4 & 17.6 \\
$N=170$ & 13 & 26 & 34 & 67 & 30 \\
\hline
\end{tabular}

Table 11

Item 50e: Teaching methodologies are recognised as disciplines in my faculty of education

\begin{tabular}{llllll}
\hline & Completely disagree & Disagree & Neither agree nor disagree & Agree & Completely agree \\
\hline Responses $(\%)$ & 7.1 & 13.5 & 25.3 & 35.9 & 18.2 \\
$N=170$ & 12 & 23 & 43 & 61 & 31 \\
\hline
\end{tabular}

Table 12

Item 50c: Teacher training programmes at my university have strong partnerships with schools in the area

\begin{tabular}{llllll}
\hline & Completely disagree & Disagree & Neither agree nor disagree & Agree & Completely agree \\
\hline Responses (\%) & 12.9 & 17.1 & 19.4 & 33.5 & 17.1 \\
$N=170$ & 22 & 29 & 33 & 57 & 29 \\
\hline
\end{tabular}


Table 13

Item 50g: My faculty of education has a high degree of cooperation with relevant arts/science faculties

\begin{tabular}{llllll}
\hline & Completely disagree & Disagree & Neither agree nor disagree & Agree & Completely agree \\
\hline Responses (\%) & 30.2 & 17.1 & 19.5 & 22.5 & 10.7 \\
$N=169$ & 51 & 29 & 33 & 38 & 18 \\
\hline
\end{tabular}

Table 14

Item 62: It is more important that university teacher training programmes emphasise teaching methods and let arts/science faculties teach subject courses

\begin{tabular}{llllll}
\hline & Strongly disagree & Somewhat disagree & Neither agree nor disagree & Somewhat agree & Strongly agree \\
\hline Responses $(\%)$ & 9.5 & 24.4 & 17.3 & 32.1 & 16.7 \\
$N=168$ & 16 & 41 & 29 & 54 & 28 \\
\hline
\end{tabular}

Table 15

Item 50i: There is good communication between my university and the Ministry of National Education

\begin{tabular}{llllll}
\hline & Completely disagree & Disagree & Neither agree nor disagree & Agree & Completely agree \\
\hline Responses $(\%)$ & 16.5 & 16.5 & 40 & 17.6 & 9.4 \\
$N=170$ & 28 & 28 & 68 & 30 & 16 \\
\hline
\end{tabular}

students more in their mind. Secondly, feelings of cooperation from teacher educators may be ambivalent as evidenced by the fact that only half of them agree with the idea that arts/science faculties should be charged with the subject area content for education students.

On further examination of the data, no structural factor of respondents' position, age or length of time in service can be related to respondent attitudes. Thus, we must consider the degree to which teacher educators are committed to this idea as being diffuse among the population.

\subsection{Improved coordination between HEC, faculties, and the Ministry of National Education}

Several items in the survey were relevant to the policy of coordination between those who train teachers and the teachers' employer. First, the respondents were asked about the quality of communication between their university and the ministry. Table 15 gives the results.

Communication with the ministry appears to be a problem among teacher educators: those who disagree with the statement exceed those who agree, with ambivalence constituting the modal response.

The response pattern could perhaps be affected by the jurisdictional issue in Turkish education: the schools are run by the Ministry of National Education, but the universities including the faculties of education are run by the HEC. The survey approached this question as given in Table 16 .

Based on the data, Turkish teacher educators agree with the present situation, whereby the ministry is not responsible for teacher training. However, the relationship between the two items in Tables 15 and $16(r=.117$, not significant $)$ does not suggest that attitudes against the ministry are influencing the result. Indeed, when asked about the support the ministry could provide, as in Table 17 , teacher educators indicated that they would welcome more interactions.

Nearly two-thirds of the sample would seek an enhanced, more helpful, relationship with the ministry, which suggests that they do not wish to disregard a relationship with the ministry on some sort of 'turf' criterion. As a consequence, this area must be regarded as a weakness in the overall restructuring effort. 
Table 16

Item 61: The Ministry of National Education is the appropriate authority to govern Turkish teacher education programmes

\begin{tabular}{llllll}
\hline & Strongly disagree & Somewhat disagree & Neither agree nor disagree & Somewhat agree & Strongly agree \\
\hline Responses $(\%)$ & 22.6 & 36.9 & 17.3 & 15.5 & 7.7 \\
$N=168$ & 38 & 62 & 29 & 26 & 13 \\
\hline
\end{tabular}

Table 17

Item 67: My job as a teacher educator would be easier with more help from the Ministry of National Education

\begin{tabular}{llllll}
\hline & Strongly disagree & Somewhat disagree & Neither agree nor disagree & Somewhat agree & Strongly agree \\
\hline Responses (\%) & 9.0 & 14.5 & 14.5 & 52.4 & 9.7 \\
$N=145$ & 13 & 21 & 21 & 76 & 14 \\
\hline
\end{tabular}

Table 18

Item 50f: Teacher training programmes at my university have adequate technology for instructional purposes

\begin{tabular}{llllll}
\hline & Completely disagree & Disagree & Neither agree nor disagree & Agree & Completely agree \\
\hline Responses $(\%)$ & 21.8 & 31.8 & 19.4 & 17.6 & 9.4 \\
$N=170$ & 37 & 54 & 33 & 30 & 16 \\
\hline
\end{tabular}

\subsection{Increased/improved technology}

One item in the survey dealt with the use of technology for instructional purposes, as shown in Table 18.

Of all the goals of the restructuring, the provision of technology is the weakest. There are special factors in the Turkish situation which exacerbate the situation, as the task was not only to bring existing faculties of education up to a technological standard but also to provide equipment and support to many new faculties. This goal was perhaps the most difficult one to implement, but nevertheless we should note that over a quarter of the respondents regarded the amount of technological resources as sufficient.

\section{Analysis and discussion}

So, how successful was the restructuring reform? Data from teacher educators across Turkey show that it was successful in increasing the number of teachers in the field; in the perception of their improved quality; in the full implementation of the master's degree requirement for high school teachers; in the greater emphasis on teaching methods and their centrality as a responsibility of teacher training institutions; and in terms of enhancing the relationship between faculties of education and local schools.

The restructuring reform was less strong in ensuring effective partnerships with arts/science faculties; in effective communication and coordination with the Ministry of National Education; and in the provision of adequate technology for instructional purposes.

In spite of the considerable changes achieved, Turkish teacher educators point out that much more needs to be done in the development of teacher training programmes. When specifically asked, their responses were as given in Table 19.

The call for further change is resounding. All except one stated the need for at least some change, up to a total reform of the system. In response to this, the HEC is currently working on further changes (Higher Education Council, 2006), and the study reported in this paper has the capacity to inform some portion of that work.

The data up to now have been viewed in aggregate terms and, while there is no evident pattern relating to the structural factors of the personal characteristics of the respondents, there is, 
however, a consistency to the data. In most of the items reviewed, just over $50 \%$ of the respondents found some to a great deal of improvement; one-quarter to one-third did not; and the remainder were equivocal. Given that structural factors do not appear to explain attitude differences, it may be that the effects of the restructuring reform were localized. In other words, the restructuring was successfully implemented in some places, and less well in others. To test this hypothesis, an inter-correlation matrix of all the major factors was generated, and the results are shown in Table 20.

On consideration of Table 20, there emerges a profile of faculties of education who have successfully implemented the restructuring. Those variables

Table 19

Item 47: Which would be nearest to your position regarding attempts to change how teacher education is done in Turkey?

\begin{tabular}{lcc}
\hline & $N$ & $\%$ \\
\hline $\begin{array}{l}\text { It is unnecessary to change the way teachers } \\
\text { are trained }\end{array}$ & 1 & 0.6 \\
$\begin{array}{l}\text { Some change is needed in how teachers are } \\
\text { trained }\end{array}$ & 55 & 32.4 \\
$\begin{array}{l}\text { Many changes are needed in how teachers } \\
\text { are trained }\end{array}$ & 61 & 35.9 \\
$\begin{array}{l}\text { The teacher education system needs to be } \\
\text { totally reformed }\end{array}$ & 53 & 31.2 \\
\begin{tabular}{l} 
Total \\
\hline
\end{tabular} & 170 & 100.0 \\
\hline
\end{tabular}

which discriminate respondent attitudes, thereby constituting differentiating items are: a focus on teaching methodologies and their status as disciplines in the faculty; strong partnerships with schools; effective cooperation with arts/science faculties; and good communication with the Ministry of National Education. These factors appear to be determinants of teacher educator perceptions about producing quality teachers. Evaluation of these factors in a linear regression format, with quality as the dependent variable, showed the results given in Table 21.

These factors working together created a relatively high multiple $R$ value and suggest strongly that they are perceived to be determinants in the production of quality teachers.

Additionally, when the above items are further computed in a stepwise regression format, the data show that only two of the factors working together, disciplines and partnerships, account for most of the differentiation that takes place $(R=.56)$. Thus, to the extent that a faculty of education incorporated disciplines and partnerships into their teacher education programme, the restructuring reform was effectively implemented. The two factors can be said to be the core of restructuring.

Although the HEC instituted some further changes with regard to changes in teacher education in 2006, and more are expected, none as yet has reinforced the importance of regarding teaching methods as disciplines, and of university partnerships with their local schools (HEC, 2006).

Table 20

Inter-correlation matrix of restructuring reform factors

\begin{tabular}{|c|c|c|c|c|c|c|c|c|c|c|c|}
\hline & $50 \mathrm{a}$ & $50 \mathrm{~b}$ & 48 & 49 & $50 \mathrm{~h}$ & $50 \mathrm{~d}$ & $50 \mathrm{e}$ & $50 \mathrm{c}$ & $50 \mathrm{~g}$ & 62 & $50 \mathrm{i}$ \\
\hline Quality & - & $.29 *$ & $-.17 *$ & $.28 *$ & .10 & $.51 *$ & $.53^{*}$ & $.42 *$ & $.27 *$ & -.08 & $.35 *$ \\
\hline Jobs & & - & -.01 & -.01 & .10 & $.25 *$ & $.26^{*}$ & $.26^{*}$ & .10 & -.05 & $.19 *$ \\
\hline Change & & & - & $-.24^{*}$ & -.03 & -.01 & -.09 & -.06 & -.02 & .02 & -.05 \\
\hline Better & & & & - & .10 & $.17 *$ & $.15^{*}$ & .09 & .09 & .02 & .09 \\
\hline Masters & & & & & - & .11 & -.07 & .04 & $.16^{*}$ & -.04 & -.01 \\
\hline Focus & & & & & & - & $.76^{*}$ & $.55^{*}$ & $.27^{*}$ & -.03 & $.34 *$ \\
\hline Disciplines & & & & & & & - & $.53^{*}$ & $.26^{*}$ & -.01 & $.41 *$ \\
\hline Partnerships & & & & & & & & - & $.34 *$ & -.12 & $.43 *$ \\
\hline $\mathrm{A} \& \mathrm{~S}$ & & & & & & & & & - & $-.26^{*}$ & $.34 *$ \\
\hline Important & & & & & & & & & & - & $-.14 *$ \\
\hline Communication & & & & & & & & & & & - \\
\hline
\end{tabular}

50a, quality of teachers trained; $50 \mathrm{~b}$, appropriate jobs for graduates; 48 , change at your university; 49 , better trained teachers; $50 \mathrm{~h}$, Master's degree for secondary teachers; 50d, strong focus on teaching methodologies; 50e, methods recognized as disciplines; 50c, strong partnerships with schools; $50 \mathrm{~g}$, cooperation with arts/sc faculties; 62, teacher training programmes should focus on methods; 50i, good communication with ministry. 
Table 21

Multiple regression equation of selected restructuring factors and the perception of producing quality teachers

\begin{tabular}{|c|c|c|c|c|c|c|c|c|c|}
\hline \multirow{3}{*}{ Model } & \multirow{3}{*}{$R$} & \multirow{3}{*}{$R$ square } & \multirow{3}{*}{ Adjusted $R$ square } & \multirow{3}{*}{ Std. error of the estimate } & \multicolumn{5}{|l|}{ Model summary } \\
\hline & & & & & \multicolumn{5}{|l|}{ Change statistics } \\
\hline & & & & & $R$ square change & $F$ change & df1 & df2 & Sig. $F$ change \\
\hline 1 & $.585(\mathrm{a})$ & .343 & .322 & .983 & .343 & 16.884 & 5 & 162 & .000 \\
\hline
\end{tabular}

(a) Predictors: (constant) strong focus on teaching methodologies; methods recognized as disciplines; strong partnerships with schools; cooperation with arts/science faculties; good communication with ministry.

\section{Conclusion}

The restructuring of Turkish faculties of education was implemented at a time of great change, both in society and in the education sector. There was also a doubling of the number of faculties of education, as new universities were set up and new faculties of education opened. Although a great deal has been accomplished, Turkish teacher educators strongly point out that more needs to be done, and it seems that the restructuring reform of teacher education in Turkey is incomplete. The study points to the two most critical factors in effective change as being the importance of teaching methodologies as disciplines and forming effective partnerships with schools. It also shows that efforts must be made to continue to incorporate the important characteristics of effective teacher education into all faculties.

\section{References}

British Council, 1999. Turkey YÖK/World Bank National Education Development Project, Pre-Service Teacher Education Component, Final Report. British Council, Manchester.

CIA, 2006. CIA World Fact Book. Central Intelligence Agency, Langley, VA.

Dundar, H., Lewis, D., 1999. Equity, quality, and efficiency: effects of reform in Turkish higher education. Higher Education Policy 12, 343-346.

Garm, N., Karlsen, G., 2004. Teacher education reform in Europe: the case of Norway; trends and tensions in a global perspective. Teaching and Teacher Education 20, 731-744.

Giddens, A., 2003. Runaway World: How Globalization is Reshaping Our Lives. Routledge, New York.

Grossman, G.M., Onkol, P.E., 2006. Towards the Europeanization of Turkish teacher education: education reform and professional development in a new context. In: Terzis, N.P.
(Ed.), Lifelong Learning in the Balkans. Kyriakidis Brothers SA, Thessaloniki, Greece, pp. 337-357.

Grossman, G.M., Onkol, P.E., Sands, M., 2007. Curriculum reform in Turkish teacher education: attitudes of teacher educators towards modernization in an EU candidate nation. International Journal of Educational Development 27, $138-150$.

Hen-Tov, E., 2004. The political economy of Turkish military modernization. The Middle East Review of International Affairs 8 (4).

Higher Education Council, 1998. Restructuring of Teacher Education Programs in Faculties of Education. Higher Education Council, Ankara.

Higher Education Council, 2006. Teacher Education Reform. Available from 〈http://www.yok.gov.tr/egitim/ogretmen/ aciklama_program.doc $\rangle$. Access date: August 11, 2006.

Kinzer, S., 2001. Crescent \& Star: Turkey between two worlds. Farrar, Straus \& Giroux, New York.

Mango, A., 2004. The Turks Today. Overlook Press, New York.

Miller, D.C., Salkind, N.J., 2002. Handbook of Research Design and Social Measurement. Sage Publications, Thousand Oaks, CA.

Ministry of National Education, 2006. Education Statistics of Turkey, 2005-06. Available from 〈http://www.meb.gov.tr/ english/indexeng.htm $\rangle$. Access date: October 142006.

ÖSYM, 2006. Available from 〈www.osym.gov.tr〉. Access date: November 172006.

Pew Global Attitudes Project, 2002. What the World Thinks in 2002. The Pew Research Center for People and the Press, Washington.

Şimşek, H., Yıldırım, A., 2001. The reform of pre-service teacher education in Turkey. In: Sultana, R. (Ed.), Challenge and Change in the Euro-Mediterranean Region: Case Studies in Educational Innovation. Peter Lang Inc., New York.

UNESCO, 2003. UN Common Database. UNESCO Publications.

UNICEF, 2003. A gender review in education, Turkey 2003. Available from 〈www.unicef.org/turkey/gr/ge2lja.html〉. Access date: November 20, 2006.

Zikmund, W.G., 2006. Business Research Methods. Dryden Press, New York. 